\title{
Practicality of Math Worksheets Based on Guided Discovery on Class VII Junior High School
}

\author{
$1^{\text {st }}$ Muthia Rahmi \\ Mathematics and Science Faculty \\ Universitas Negeri Padang \\ Padang, Indonesia \\ rahmimuthia.90@gmail.com
}

\author{
$2^{\text {nd }}$ Yerizon \\ Mathematics and Science Faculty \\ Universitas Negeri Padang \\ Padang, Indonesia
}

\begin{abstract}
Mathematical communication ability is one of the abilities that students must possess. With the communication skills, students can interpret their own ideas both verbally and in writing and can communicate their mathematical thoughts to others well. One of the efforts offered to support the improvement of student communication is the development of Student-Based Worksheets (LKPDs). The purpose of this study is to produce guided discovery-based LKPD to improve mathematical communication skills in MTs / SMP. The model used in this study is the Plomp model. This model consists of preliminary research phase, prototype phase and assessment phase. The results of the research on the development of guided discovery-based LKPD are practical.
\end{abstract}

Keywords-Guided Discovery, Model Plomp, Practicality

\section{INTRODUCTION}

One of the basic sciences that students must have that will form a critical mindset is mathematics. This mindset can be formed in the learning of mathematics if each student is able to understand mathematics well. Mathematics subjects need to be given to students with the ability to think logically, systematically, critically and creatively and the ability to work together. Some of the objectives of mathematics learning are explained in the Regulation of the Minister of Education and Culture of the Republic of Indonesia Number 58 of 2014 [1] are: 1). Communicate ideas, reasoning and be able to compile mathematical evidence by using complete sentences, symbols, tables, diagrams, or other media to clarify the situation or problem. 2). Having an attitude of respect for the usefulness of mathematics in life, namely having curiosity, attention, and interest in learning mathematics, as well as tenacity and self in problem-solving.

Referring to the purpose of mathematics learning which was explained by the Republic of Indonesia Minister of Education and Culture Regulation No. 58 of 2014 [1], one of the abilities that students must master is mathematical communication skills. This is similar to what Mahmudi stated [2] that mathematical communication is one of the graduation competency standards in the field of mathematics of school students from elementary to secondary education. Mathematical communication skills of students need to be considered, in addition to graduation standards, mathematics communication is a method used by students to express a mathematical idea or idea both verbally and in writing that can describe a person's thinking process.
Astuti and Leonard [3] explained that communication skills need to be developed in the process of learning mathematics because it is one of the graduation standards. In line with that Hodiyanto [4] explains in the learning process in school, especially mathematics learning, communication skills can be developed, this is because mathematics is one of the logic sciences that is able to develop students 'thinking skills, thus mathematics has a role to develop students' communication skills. The Ministry of National Education in Shadiq [5] proposes mathematical communication that students are able to express and interpret mathematical ideas verbally, in writing, or demonstrate.

The results of interviews with several students and some teachers at Solok MTsN 3, obtained information that students were still having difficulties when answering questions in the form of stories. Students find it difficult to interpret and understand problems in mathematical and drawing forms. Some students can solve the questions given but they have difficulty when asked by the teacher to present the results of the answers in front of the class. In addition students can solve problems with the right results but the completion steps are not well structured, this is a result of lack of trained students in communicating mathematics in oral and written form.

When students have difficulty answering the questions given, the students tend to wait for answers from the teacher so that students only receive and are not trained in constructing their own knowledge in solving the questions learned. This is what shows the lack of active students, which results in low learning outcomes which is evident from the value of mathematics learning outcomes which are still below the Minimum Completeness criteria (KKM) which is 75. The teacher's efforts in activating students in the learning process have been seen from providing teaching materials in the form of LKPD, but the LKPD provided is not the result of the teacher's development. The LKPD that is used today is still LKPD which was developed by other mathematics teachers who were purchased to be printed. This is very influential because not all contents in LKPD are in accordance with the characteristics of students. Based on the analysis conducted on LKPD, it is seen that the presentation of the material is directed at the core of the material. Students are immediately given the concept of the subject matter. In the LKPD it has not been supported by activities that actively involve students in making discoveries to build concepts on the material being studied. Lack of student involvement in building their own knowledge results in students being prone to memorizing formulas and students are easily forgetting the formula. 
Regardless of the problems above, we should not be able to only blame the teacher and students if a learning process does not run smoothly, to overcome the problems that occur in class mathematics learning, an effort is needed in choosing models and teaching materials in learning. Teachers are required to be more creative, innovative, placing students not only as objects of learning

But it is also the subject of learning and ultimately leads to a fun and active learning process. Based on the problems presented, it is necessary to develop a mathematics teaching material, namely guided discovery-based teaching materials that can facilitate students to construct their own knowledge. Risnawati [6] revealed a guided discovery model is a way of delivering mathematical topics in such a way that in the learning process allows students to find their own patterns or structures of mathematics through a series of past learning experiences and cannot be separated from teacher supervision and guidance. Suherman's opinion [7], "On guided discovery the teacher gives instructions, directions, statements or dialogue to a conclusion about the material being taught, the guidance given by the teacher depends on the ability of the students and the topic being taught". Yulianti [8] explained that discovery is guided by a model that helps pesetas students to be active in the learning process, where students will think and find their own knowledge. Yusnita [9] stated that in the implementation of guided methods can make students active and can find knowledge by themselves and help students improve their reasoning power to understand something. The guided discovery learning in this study was conducted in groups. Group discussion allows students to practice expressing understanding, verbalizing the thought process, and clarifying their understanding or understanding. In the process of group discussion, there will be an exchange of ideas and thoughts between students. This will give students the opportunity to build their mathematical understanding. Teaching materials that will be developed to support students' mathematical communication skills will take the form of LKPD. LKPD contains steps for activities that must be carried out by students to find concepts of learning and exercises. As stated by the Ministry of National Education [10] that LKPD contains tasks that must be done by students, usually in the form of instructions and steps to complete a task. LKPD contains a set of activities, problems or problems that students will do during learning. Based on the description above, a study was carried out entitled: "Development of Guided Discovery-Based Learning Devices to Improve the Communication Ability of Class VIII MTs / SMP Students". However, what will be discussed at this time is limited only to see the practicalities of the LKPD produced.

\section{METHODS}

The plomp model is the development model used in this study. This model consists of the initial investigation phase (preliminary research), the development phase or prototyping stage, and assessment stage. In more detail described as follows: 1. Preliminary research phase (preliminary research) In this phase the collection of information related to learning in the classroom is carried out and several analyzes are carried out to obtain information for the development of LKPD that will be carried out such as (a)
Needs analysis, (b) curriculum analysis, (c) analysis of students, (d) concept analysis.

2. Phase of Prototype Making (Development or Prototyping Phase)

This phase is designed guided discovery-based LKPD using Tessmer formative evaluation. LKPD is designed according to the results of the preliminary research phase. The steps taken at the Prototype manufacturing stage are (a) designing LKPD according to the results of Preliminary research, (b) self-evaluation, (c) assessment of experts, (d) evaluation of one on one, and (e) evaluation of small groups.

\section{Assessment Phase}

This phase is done after all stages of prototype creation are complete. The assessment phase is the summative evaluation, which is by conducting practicality and effectiveness tests. The assessment phase was carried out in the eighth grade of Solok MTsN 3 with 35 students. Learners assisted by guided discovery-based LKPD. At this stage will be seen the practicality and effectiveness of the product developed by looking at the learning outcomes and activities of students.

\section{IIII. RESULTS AND DISCUSSION}

\section{Preliminary Research Phase (preliminary research) a. Needs Analysis.}

Information needs analysis is done by looking at the learning process directly and interviews with teachers. Based on observations into the class, the learning process has not taken place optimally. Activities in the classroom are more teacher-centered, while students receive more knowledge than find it themselves. Not all students have a high interest in the learning process.

Based on the results of interviews with teachers, information was obtained that students' understanding of material was low. Students are very difficult when working on questions in the form of narratives, there are also students who can solve the problem with the right results but the steps to solve it are not well structured as a result of lack of trained students in communicating mathematics in oral and written form. Based on the results of the questionnaire analysis given to students, it was concluded that students wanted an LKPD that was interesting to read, such as having attractive colors and pictures and the desired LKPD having less difficult questions.

\section{b. Curriculum Analysis}

Curriculum analysis is carried out by reviewing the 2013 curriculum for grade VIII mathematics lessons in the second semester used in MTsN 3 Solok. Based on the syllabus, KD will be used in accordance with the syllabus. However, there is an addition to the GPA in building the flat-side space, as well as learning objectives tailored to the added GPA.

\section{c. Concept Analysis}

Concept analysis is carried out by identifying and composing the main concepts of material building up the flat side space that students will learn systematically. The 
preparation of the main material is carried out so that students easily understand the material provided. The material to be studied in the second semester are Pythagoras, circles, building flat side spaces, comparisons, and opportunities. However, this study will study the building material of flat side space. The main concepts in the material of building a flat side space are (1) building a cube space, (2) building a beam space, (3) building a prismatic space, and (4) building a pyramid space.

d. Student Analysis The sample in this study was taken on the eighth-grade students of Solok MTsN 3, totaling 30 people who have heterogeneous academic abilities, ranging from those with low, medium and high abilities. Students still have many difficulties in learning mathematics, especially in understanding and solving problems in the form of stories. Students say they prefer if the learning process is done in groups. In addition, students stated that the LKPD that students want is dominant in blue, the language used must be clear, have an attractive appearance, have images that match the material and the size of the LKPD used is usually A4.

\section{Phase of Prototype Making (Development or Prototyping} Phase)

In the phase of making this prototype, researchers designed the LKPD based on the results of preliminary research. The LKPD to be developed must be in accordance with a guided discovery-based learning model. In the development of guided discovery-based LKPD has several characteristics. The characteristics of LKPD are divided into 3 parts, namely aspects of content, aspects of presentation and aspects of language or legibility. Based on the aspects of the contents of the LKPD, it is prepared in accordance with the steps of guided discovery-based learning that guides students to be able to find their own knowledge and can improve students' communication skills. Based on aspects of the presentation of LKPD arranged sequentially starting from the designed cover illustrating the content of LKPD material, preface and table of contents, basic competencies, learning objectives, and learning instructions of students, data of students, the introduction of materials and numbering of LKPD. Based on aspects of language and legibility, the language used in LKDP in accordance with EYD is correct and easily understood in accordance with students. The size of the letters and the shape of the letters are in accordance with the readability of students. The size of the LKPD that is made in accordance with the students' request is A4 $21 \mathrm{~cm}$ x $29.7 \mathrm{~cm}$. Type of writing on LKPD generally Comic sans MS with size 12. After the LKPD design is complete, the next step is to evaluate the device based on Tesmer formative evaluation including:

\section{a. Self Evaluation}

The evaluation itself is carried out to see the components of LKPD that have been made, whether there is something that is lacking and not yet right. In addition, the evaluation itself is also to see if there are still errors in the writing of the term words, punctuation, inappropriate images, incorrect placement of images, and errors in typing sentences or letters. The results of the evaluation itself still have many errors in the use of punctuation, typing letters that are wrong, the use of hyphens, the use of capital letters at the beginning of the sentence or in a word.

\section{b. Expert Reviews}

The next step after self-evaluation is the validation of experts. Validation for LKPD is given to experts as many as five people to assess whether the LKPD used is in accordance with the aspects of presentation, aspects of the feasibility of content, aspects of graphics and aspects of language. The results of the validation of the presentation aspects are very valid with the 3.46 validity value indicating that the presentation of the LKPD display is systematically arranged starting from the cover, instructions and learning steps. The validation results on the content aspect are very valid with a 3.64 validation value, this shows that the material contained in the LKPD refers to the 2013 curriculum and fulfilled guided discovery steps. Whereas seen from the validation results on the graphical aspect which is very valid with a validity value of 3.28 , this shows proportional font shape and size, layout of the contents, images, colors and designs look attractive. So based on the assessment of several lecturers on the guided discovery-based LKPD developed, it can be concluded that LKPD has an overall validity value of 3.47 with very valid criteria. Validator's suggestion for LKPD improvement starts from cover repairs, use of punctuation, layout of text and images. Researchers improve the LKPD according to the validator's suggestion, the results of this LKPD improvement are called prototype 2 .

\section{c. One-to-One Evaluation}

This stage is carried out by asking 3 students to work on the LKPD that has been designed and provide feedback or suggestions regarding LKPD. The purpose of one-on-one evaluation is to identify possible errors such as grammar that is poorly understood, the possibility of spelling that is still wrong, unclear instructions, and suitability — suitability of the image and attractiveness of the display. This one-on-one evaluation phase was held in 6 meetings. From this meeting, there was a revision of the LKPD regarding the addition of the LKPD usage instructions section, changes in several sentences to be easily understood, the addition of several questions so that students better understand the material and add columns to fill in the students' answers. The results of interviews with students concluded that LKPD which was designed to help students communicate their mathematical ideas, made learning more interesting, even though there were several questions and steps that were difficult for students to understand. Based on the students' input towards LKPD, a revision was made, the result of the LKPD revision was called the prototype 3 .

d. Small Group Evaluation (Small Group Evaluation) The revised results of the small group evaluation were tested again for students consisting of 9 people who had different learning abilities. In this small group evaluation, researchers will act as teachers and carry out the learning process as usual. Students are divided into 3 groups and asked to work on the given LKPD and provide responses to the resulting guided discovery-based LKPD. After a trial of 6 meetings, students were asked to fill out a practical questionnaire and 
conduct an interview. This questionnaire was given to see the practicalities of LKPD. The results of the practicality questionnaire filled in by students can be seen in Table 1 .

TABle 1. Results of the SMall Group try Out Practical QUESTIONNAIRE

\begin{tabular}{|r|c|c|l|}
\hline No & $\begin{array}{c}\text { Aspek yang } \\
\text { Dinilai }\end{array}$ & $\begin{array}{c}\text { Nilai } \\
\text { Kepraktisan (\%) }\end{array}$ & Kategori \\
\hline 1 & Penyajian & 90,1 & Sangat Praktis \\
\hline 2 & Kegunaan & 83,7 & Praktis \\
\hline 3 & Keterbacaan & 76,4 & Praktis \\
\hline 4 & Waktu & 86 & Sangat Praktis \\
\hline \multicolumn{2}{|r|}{ Nilai rata-rata kepraktisan } & 84,05 & Praktis \\
\hline
\end{tabular}

Based on table 1, the average value of LKPD practicality is $84.05 \%$ with practical criteria. LKPD is said to be practical because based on its presentation it has a value of $90.1 \%$ with very practical criteria as evidenced by students already understanding the LKPD usage instructions, students also really like the size and type of letters, the paper size makes it easy for students to use LKPD, colors and covers and pictures contained in the LKPD is very interesting. Based on the usefulness of LKPD it is said to be practical with a value of $83.7 \%$ because students can understand the problems contained in LKPD, students are interested in solving problems and obtaining new knowledge through activities contained in LKPD and can understand the subject matter and can work on questions which are easily presented. Based on the readability aspect, LKPD has a value of $76.4 \%$ with practical criteria because students easily read each letter, word and sentence and can understand the sentences used in LKPD and compare based on the time students can carry out activities on LKPD according to the time given value of $86 \%$, with very practical criteria. Thus it can be concluded that in this small group test phase guided discovery-based LKPD is used practically. The results of this small group test revision are called prototype 4 .

\section{Assessment Phase}

After getting the prototype 4 the next stage is the field test stage. LKPD was tested on research subjects, namely class VIII G MTsN 3 Solok as many as 35 people. Participants were divided into 6 groups. The trial in this field test was carried out as many as 6 meetings. At this field test phase the researcher is assisted by a mathematics teacher who will teach in the class. At this stage it was seen the practicality and effectiveness of the LKPD that was developed. Practicality of learning tools can be seen from the results of questionnaire analysis which is filled by teachers and students. Based on the results of the practicality questionnaire the learning tools filled in by the teacher obtained data in Table 2:
TABle II. RESUlts OF THE ANALYSIS OF THE PRACTICALITY QUESTIONNAIRE OF THE DEVICE BY THE TEACHER

\begin{tabular}{|c|c|c|c|}
\hline No & $\begin{array}{l}\text { Aspek yang } \\
\text { Dinilai }\end{array}$ & Nilai Kepraktisan & Kategori \\
\hline 1 & Daya Tarik & 87,5 & Sangat Praktis \\
\hline 2 & $\begin{array}{l}\text { Proses } \\
\text { Penggunaan }\end{array}$ & 83,4 & Sangat Praktis \\
\hline 3 & $\begin{array}{l}\text { Kemudahan } \\
\text { Penggunaan }\end{array}$ & 75 & Praktis \\
\hline 4 & Waktu & 75 & Praktis \\
\hline \multicolumn{2}{|c|}{ Nilai rata-rata kepraktisan } & 80,22 & Praktis \\
\hline
\end{tabular}

Based on Table 2 shows that the average value of the practicality of the device is $80.22 \%$ with practical criteria. Parangkat is said to be practical because based on the teacher's assessment the attractiveness of the device is very practical with a value of $87.5 \%$, this is because LKPD has an attractive appearance and color design. Based on the use process, LKPD has very practical criteria with a value of $83.4 \%$, the teacher assesses that LKPD can help students to acquire new knowledge and the device can involve active students in learning. Whereas based on ease of use, LKPD has a practical criterion with a value of $75 \%$, the teacher assesses that LKPD makes it easy for students to remember the material and help students improve their communication skills. While the teacher's assessment of the aspect of time, LKPD has a practical criterion with a value of $75 \%$ because the learning steps are in accordance with the time specified and the use of LKPD in accordance with the available time. Based on aspects that have been assessed by the teacher, it was concluded that the developed devices based on guided findings were declared practical.

After students have carried out the learning process for 6 meetings, the researcher gives a practical questionnaire to students. The LKPD practicality questionnaire recapitulation that has been filled in by students can be seen in Table 3 .

TABle III. Results OF THE ANALysis OF LKPD PRACTICAL QUESTIONNAIRE BY STUDENTS

\begin{tabular}{|l|l|c|c|}
\hline No & Aspek yang Dinilai & $\begin{array}{c}\text { Nilai } \\
\text { Kepraktisan } \\
(\%)\end{array}$ & Kategori \\
\hline 1 & Penyajian & 89,50 & Sangat Praktis \\
\hline 2 & $\begin{array}{l}\text { Kemudahan } \\
\text { Penggunaan }\end{array}$ & 82,14 & Praktis \\
\hline 3 & Keterbacaan & 91,13 & Sangat Praktis \\
\hline 4 & Waktu & 84,67 & Praktis \\
\hline \multicolumn{2}{|l|}{ Nilai rata rata kepraktisan } & 86,86 & Sangat Praktis \\
\hline
\end{tabular}

Based on Table 3, the average practicality of LKPD assessed by students is $86.86 \%$ with a very practical category. LKPD is said to be practical because based on its presentation it has a value of $89.5 \%$ with this very practical criterion as evidenced by students already understanding the LKPD usage instructions, students also really like the size and type of letters, the paper size makes it easy for students to use LKPD, colors and covers and pictures contained in the 
LKPD is very interesting. Based on the usefulness of LKPD it is said to be practical with a value of $82.14 \%$ because students can understand the problems contained in LKPD, students are interested in solving problems and obtaining new knowledge through activities contained in LKPD and can understand the subject matter and can work on questions which is easily presented. Based on the readability aspect, LKPD has a value of $91.13 \%$ with very practical criteria because students easily read each letter, word and sentence and can understand the sentences used in LKPD and compare based on the time students can carry out activities on LKPD according to the time given with a value of $84.67 \%$, with very practical criteria. It can be concluded, that guided discovery-based LKPD based on practicality questionnaire that has been filled by students have practical criteria can be used well by students.

\section{CONCLUSION}

Based on the results of the implementation of the study, it was concluded that the implementation of development research had produced a learning tool in the form of guided discovery-based LKPD with a practical category both used by the teacher and by students.

\section{REFERENCES}

[1] Peraturan menteri Pendidikan dan Kebudayaan Nomor 58 Tahun 2014,Jakarta: Kemendikbud, 2014.

[2] Mahmudi. Ali, "Komunikasi Dalam Pembelajaran Matematika". Jurnal MIPMIPA UNHALU,ISSN 1412-2318. Volume 8, Nomor 1, Februari 2009

[3] Astuti. Leonard, "Peran Kemampuan Komunikasi Matematika Terhadap Prestasi Belajar Matematika Siswa”, ISSN: 2088-351X

[4] Hodiyanto, "Kemampuan Komunikasi Matematis Dalam Pembelajaran Matematika”, ISSN : 2088-687X, 2014.

[5] Shadiq. Fadjar, Kemahiran Matematika, Yogyakarta Depdiknas, (2009).

[6] Risnawati, Strategi Pembelajaran Matematika, Pekanbaru: Suska Press, 2008.

[7] Suherman. E, Startegi Pembelajaran Matematika Komtemporer, JICA. UPI Bandung, 2001.

[8] Yulianti, "Pengaruh Model Penemuan Terbimbing Terhadap Kemampuan Komunikasi Matematika Ditinjau dari Motivasi Belajar Siswa", Jurusan Pendidikan Matematika FMIPA Universitas Negeri Gorontalo, 2014.

[9] Rahmawati. Yusnita, "Pengembangan Perangkat Pembelajaran Berbasis Penemuan Terbimbing (Guided Discovery) dengan Pendekatan Somatic, Auditory, Visual, Intellectual (SAVI) Pada Materi Pokok Peluang Kelas IX SMP Tahun Pelajaran 2013/2014", Jurnal Elektronik Pembelajaran Matematika ISSN: 2339-1685 Vol.2, No.4, hal 379 - 388, Juni 2014.

[10] Depdiknas, Panduan Pengembangan Bahan Ajar, Jakarta: Direktorat Jenderal Manajemen Pendidikan Dasar dan Menengah, 2008. 